\title{
The impact of VAM on goodwill impairment -Based on civil engineering construction industry
}

\author{
Ping $\mathrm{Yi}^{1, *}$ \\ ${ }^{1}$ Department of Accounting, Beijing jiaotong University, 100089 Beijing, China
}

\begin{abstract}
Based on the background of the Ministry of Finance's concern about the issue of goodwill impairment and the frequent outbreak of goodwill impairment risk, this paper analyzes the difference in the proportion of goodwill impairment during the valuation adjustment mechanism ( VAM ) period and after the VAM period, with a view to providing theoretical and data reference suggestions for the standard-setters and regulators on preventing goodwill impairment risk and improving the relevant regime of VAM, and also providing theoretical support and risk warning for stakeholders in M\&A. Combining the normative research method and the empirical research method, this paper takes the merger and acquisition event completed by the A-share listed companies of civil engineering construction industry in 2014-2016 as the initial sample, and studies the difference in the proportion of goodwill impairment during the VAM period and after the VAM period. The conclusion of this paper is: In the merger and acquisition transaction with VAM, the proportion of goodwill impairment of listed companies after the VAM period are greater than that of the VAM period.
\end{abstract}

\section{Introduction}

On January 4, 2019, the Accounting Standards Committee of the Ministry of Finance issued "Feedback from the Advisory Committee on some issues of the Accounting Standards Advisory Forum" to discuss the follow-up accounting treatment of goodwill, and believed that the follow-up accounting treatment of goodwill should be amortized. As members of the Finance Department's accounting standards advisory committee discussed the issue of impairment or amortization of goodwill, coupled with the existence of the huge goodwill in the consolidated balance sheet of A-share listed companies, goodwill impairment has become one of the hot topics in China's capital market. So, what is the current situation of China's goodwill impairment? Table 1 shows the distribution of the number of enterprises with goodwill impairment of all A-share listed companies in China from 2010 to 2019.

Table 1. Distribution of the number of enterprises with goodwill impairment by A-share listed companies in 20102019.

\begin{tabular}{|c|c|c|c|l|}
\hline Year & $\begin{array}{l}\text { Number of } \\
\text { listed firms }\end{array}$ & $\begin{array}{l}\text { Number of } \\
\text { firms with } \\
\text { goodwill }\end{array}$ & $\begin{array}{l}\text { Number of } \\
\text { firms who took } \\
\text { goodwill } \\
\text { impairments }\end{array}$ & $\begin{array}{l}\text { Proportio } \\
\text { n of firms } \\
\text { with } \\
\text { goodwill } \\
\text { impairme } \\
\text { nts (\%) }\end{array}$ \\
\hline 2010 & 1993 & 667 & 57 & 8.55 \\
\hline 2011 & 2270 & 815 & 72 & 8.83 \\
\hline 2012 & 2424 & 972 & 103 & 10.60 \\
\hline 2013 & 2426 & 1094 & 140 & 12.80 \\
\hline 2014 & 2550 & 1251 & 154 & 12.31 \\
\hline 2015 & 2773 & 1512 & 255 & 16.87 \\
\hline
\end{tabular}

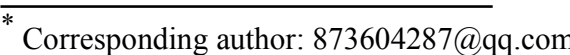

\begin{tabular}{|l|l|l|l|l|}
\hline 2016 & 3000 & 1713 & 353 & 20.61 \\
\hline 2017 & 3438 & 1927 & 473 & 24.55 \\
\hline 2018 & 3543 & 2107 & 874 & 41.48 \\
\hline 2019 & 3746 & 2189 & 842 & 38.47 \\
\hline
\end{tabular}

As shown in Table 1, the risk of goodwill impairment of listed companies in China have erupted frequently in 2010-2019, with the impairment of goodwill in 2018 being particularly severe. In 2010-2019, the proportion of entrepreneurs with goodwill impairments increased gradually, of which the proportion of entrepreneurs with goodwill impairments in 2018 was 41.48 percent.

According to Wind database statistics, in 2015, listed companies made large-scale asset acquisitions, the number of completed mergers and acquisitions reached 4,128. Most listed companies in mergers and acquisitions have a VAM (Fang Zhong etc.,2016) and the VAM period is mostly 3 years. So, is the outbreak of goodwill impairment in 2018 due to the expiration of VAM?

Based on the above questions, this paper analyzes the difference in the proportion of goodwill impairment during the VAM period and after the VAM period, with a view to providing theoretical and data reference suggestions for the standard-setters and regulators on preventing goodwill impairment risk and improving the relevant regime of VAM, and also providing theoretical support and risk warning for stakeholders in M\&A.

\section{Review}

In the existing literature, there are few literatures on the relationship between VAM and goodwill impairment. 
Huang Hong and Zhong Zhiming (2020) through empirical research found that during the VAM period, VAM can effectively inhibit goodwill impairment, but when the VAM period ends, goodwill impairment will be significantly increased. Tian Guoshuang and $\mathrm{Gu}$ Manjia (2020) further found that during the VAM period, target companies that have not fulfilled their VAM will increase goodwill impairment, and the reorganization method can significantly adjust the negative correlation between VAM and goodwill impairment, that is, for nonrelated reorganizations, signing VAM can promote acquirers to reduce goodwill impairment.

\section{Research Hypothesis}

First of all, VAM has an incentive effect, is conducive to incentivizing the target companies' management to continue to work hard to achieve the VAM, the acquirer will therefore have good expectations of goodwill, so that in the VAM period to reduce goodwill impairment. However, after the VAM period, the target enterprises lose the incentive effect of VAM, it is difficult to maintain efficient business ability, goodwill impairment risk will increase.

Second, according to the incentive and restraint effect, the VAM will exert great pressure on the enterprises, once the trigger share compensation will weaken the control of the target enterprises, and even cash compensation will cause the target enterprises to lose profits (Xie Haidong, Tan Yining,2018). As a result, the enterprises whose compensation are triggered will avoid the trigger of compensation through earnings management. And when compensation matters are triggered, enterprises will also use earnings management to reduce compensation liability. In summary, it is known that the target enterprises with VAM will improve performance through earnings management during the VAM period, thus reducing the risk of goodwill impairment during the VAM period.

However, the higher the level of earnings management, the lower the efficiency of its future investment (Ren Chunyan,2012). From the perspective of the future business performance of enterprises, earnings management will also have a negative impact on the future business performance of enterprises (Wang Fusheng et al.,2014). Therefore, in the merger and acquisition transaction with VAM, the probability of performance loss of the target enterprises will increase after the VAM period, and the proportion of goodwill impairment of listed companies after the VAM period will also increase. Based on this, this paper presents:

H1: In mergers and acquisitions with VAM, the percentage of goodwill impairments of listed companies after the VAM period are greater than during the VAM period.

\section{Research Design}

\subsection{Sample Selection and Data Source}

This paper takes the merger and acquisition event completed by the A-share listed companies of civil engineering construction industry in 2014-2016 as the initial sample, and the period of goodwill impairment and control variables is from 2014 to 2019.This paper manually collates the VAM signing and VAM period of each merger and acquisition event by querying the merger announcement on the exchange's website, and the other data in this paper comes from the Wind database and the CSMAR database.

In order to obtain sufficient and accurate information, this paper performs the following screening of samples:

- Excluding the sample of acquirer or target companies as financial industry;

-Excluding samples whose control rights have not changed;

-Excluding samples with 0 goodwill;

- Excluding samples that have not VAM;

- Excluding samples with missing relevant data.

\subsection{Variable Definition}

\subsubsection{Explained variable}

Referring to Liu Aiming and Huang Wei's research (2019), this paper measures goodwill impairment (GWI) by goodwill impairment for current period/goodwill for current period.

\subsubsection{Explanatory variable}

Referring to Rao Xi and Hou Xipei's research (2017), this paper selects the virtual variable to measure whether after the VAM period (VAM), after the VAM period, take 1 , otherwise take 0 .

\subsubsection{Control variables}

Referring to previous studies on goodwill impairment, this paper selects return on total assets, debt-to-asset ratio, size of the board of directors, whether the internal control is defective, executive change, executive compensation, audit quality and audit opinions as the control variables of this paper. Table 2 defines all the variables covered in this paper.

Table 2. Variable Definition Table

\begin{tabular}{|c|c|c|c|}
\hline Variable type & $\begin{array}{c}\text { Variable } \\
\text { name }\end{array}$ & $\begin{array}{c}\text { Variable } \\
\text { name }\end{array}$ & $\begin{array}{c}\text { Variable } \\
\text { definitions }\end{array}$ \\
\hline Explained variable & $\begin{array}{c}\text { The } \\
\text { percentage of } \\
\text { goodwill } \\
\text { impairment }\end{array}$ & GWI & $\begin{array}{l}\text { Goodwill } \\
\text { impairment for } \\
\text { current period } \\
\text { /Goodwill for } \\
\text { current period. }\end{array}$ \\
\hline Explanatory variable & $\begin{array}{l}\text { Whether after } \\
\text { the VAM } \\
\text { period }\end{array}$ & VAM & $\begin{array}{l}\text { Virtual variable, } \\
\text { when the current } \\
\text { period is after the } \\
\text { VAM, take 1, } \\
\text { otherwise take 0. }\end{array}$ \\
\hline
\end{tabular}




\begin{tabular}{|c|c|c|c|}
\hline Variable type & $\begin{array}{c}\text { Variable } \\
\text { name }\end{array}$ & $\begin{array}{c}\text { Variable } \\
\text { name }\end{array}$ & $\begin{array}{c}\text { Variable } \\
\text { definitions }\end{array}$ \\
\hline \multirow{8}{*}{ Control variables } & $\begin{array}{l}\text { Return on } \\
\text { total assets }\end{array}$ & Roa & $\begin{array}{llr}\text { Return on total } \\
\text { assets for the } \\
\text { period. }\end{array}$ \\
\hline & $\begin{array}{c}\text { The ratio of } \\
\text { assets - } \\
\text { liabilities }\end{array}$ & Lev & $\begin{array}{l}\text { Liabilities at the } \\
\text { end of the period } \\
\text { Total assets at the } \\
\text { end of the period. }\end{array}$ \\
\hline & \begin{tabular}{|c|}
$\begin{array}{c}\text { The size of } \\
\text { the board of } \\
\text { directors }\end{array}$ \\
\end{tabular} & Board & $\begin{array}{l}\text { Number of board } \\
\text { members of the } \\
\text { acquirer }\end{array}$ \\
\hline & \begin{tabular}{|} 
Whether \\
internal \\
controls are \\
defective \\
\end{tabular} & Inc & $\begin{array}{l}\text { Virtual variable, } \\
\text { internal control } \\
\text { has defects take } 1 \text {, } \\
\text { otherwise take } 0 .\end{array}$ \\
\hline & $\begin{array}{l}\text { Executive } \\
\text { changes }\end{array}$ & $\mathrm{Mgt}$ & $\begin{array}{l}\text { Virtual variable, } \\
\text { If the chairman or } \\
\text { general manager } \\
\text { changes in the } \\
\text { current year, take } \\
1 \text {, otherwise take } \\
0 \text {. }\end{array}$ \\
\hline & $\begin{array}{c}\text { Executive } \\
\text { compensation }\end{array}$ & Pay & $\begin{array}{l}\text { Natural logarithm } \\
\text { of the total } \\
\text { compensation of } \\
\text { the top three } \\
\text { executives. }\end{array}$ \\
\hline & Audit quality & Big10 & $\begin{array}{l}\text { Virtual variable, } \\
\text { when the audit } \\
\text { institution is in } \\
\text { the top } 10 \text { of } \\
\text { China, take } 1 \text {, } \\
\text { otherwise take } 0 .\end{array}$ \\
\hline & $\begin{array}{c}\text { Audit } \\
\text { opinions }\end{array}$ & Aud & $\begin{array}{l}\text { If the current year } \\
\text { is a standard } \\
\text { unqualified } \\
\text { opinion, take } 1 \text {, } \\
\text { otherwise take } 0 .\end{array}$ \\
\hline
\end{tabular}

\subsection{Model Setting}

In this paper, the logit model (1) tests H1 and discusses the difference in the proportion of goodwill impairment during the VAM period and after the VAM period.

$$
G W I=\alpha+\beta V A M+\sum \gamma \text { Controls }+\varepsilon
$$

In model (1), GWI represents the percentage of goodwill impairment. VAM represents whether after the VAM period, and Controls summarizes the control variables in Table 2.

\section{The Empirical Results and Analysis}

\subsection{Descriptive Analysis}

The sample interval of this paper is 2014-2019, and Table 3 is the distribution of the sample and the mean of the major variables for each year.

Table 3. Descriptive statistics of variables.

\begin{tabular}{|c|c|c|c|c|}
\hline Variable & mean & sd & min & max \\
\hline GWI & 0.363 & 1.858 & 0 & 14.155 \\
\hline VAM & 0.333 & 0.475 & 0 & 1 \\
\hline Roa & 2.902 & 6.480 & -25.447 & 12.549 \\
\hline Lev & 0.541 & 0.173 & 0.188 & 0.832 \\
\hline Board & 8.833 & 1.248 & 6 & 12 \\
\hline
\end{tabular}

\begin{tabular}{|c|c|c|c|c|}
\hline Inc & 0.242 & 0.432 & 0 & 1 \\
\hline Mgt & 0.348 & 0.480 & 0 & 1 \\
\hline Pay & 14.402 & 0.609 & 12.888 & 15.227 \\
\hline Big10 & 0.621 & 0.489 & 0 & 1 \\
\hline Aud & 0.924 & 0.267 & 0 & 1 \\
\hline
\end{tabular}

As we can see from the statistics, the mean of GWI in the sample is 0.36 , which means that the average proportion of goodwill impairment is $36 \%$, and the mean of VAM is 0.33 , which means that approximately $33 \%$ of the sample's VAM has expired.

\subsection{Regression Analysis}

The regression result of the model (1) is shown in Table 4:

Table 4. Regression Results

\begin{tabular}{c|c|c|c}
\hline \multirow{2}{*}{ Variable } & \multicolumn{3}{|c}{ Model } \\
\cline { 2 - 4 } & Coef. & $\mathbf{z}$ & $\mathbf{P}>|\mathbf{z}|$ \\
\hline Cons & 5.381 & 0.49 & 0.623 \\
\hline VAM & $2.330^{* *}$ & 2.95 & 0.003 \\
\hline Roa & -0.002 & -0.03 & 0.975 \\
\hline Lev & 0.728 & 0.31 & 0.755 \\
\hline Board & -0.787 & -1.89 & 0.059 \\
\hline Inc & $-2.192^{*}$ & -2.08 & 0.037 \\
\hline Mgt & -0.944 & -1.15 & 0.249 \\
\hline Pay & 1.170 & 0.24 & 0.813 \\
\hline Big10 & 0.901 & 0.93 & 0.352 \\
\hline Aud & -2.780 & -1.73 & 0.083 \\
\hline \multicolumn{4}{|c}{ Prob $>$ chi2 0.0085} \\
& Pseudo R2 0.2593 \\
\hline
\end{tabular}

The results of the model (1) can be seen VAM is positive and significant, verify $\mathrm{H} 1$, indicating that in mergers and acquisitions with VAM, the percentage of goodwill impairments of listed companies after the VAM period are greater than during the VAM period.

\section{Conclusion and Recommendations}

Through theoretical analysis and empirical testing, this paper finds that the percentage of goodwill impairments of civil engineering company after the VAM period are greater than during the VAM period. After the VAM period, the target enterprises lose the incentive effect of the VAM, it is difficult to maintain the efficient business ability, and the risk of goodwill impairment will increase. In addition, the target enterprises with VAM will improve performance through the earnings management during the VAM period, and the higher the level of earnings management, the probability of the performance loss of the target enterprises after the VAM period will increase, and the listed companies' goodwill impairment will increase.

Based on the conclusions of this paper, the following recommendations are made:

- Appropriately extending the VAM period to reduce the probability and level of earnings management of the target enterprises.

- Taking measures after the VAM period to compensate for the losses caused to listed companies by goodwill impairment, such as adding impairment testing of the target assets within a few years of the VAM period. 


\section{References}

1. Fang Zhong, Cheng Yang, Xiao Yuan. Current situation and Supervision of Performance Commitment of M\&A [J]. Tsinghua Finance Review,2016(10):73-79.

2. Huang Hong, Zhong Zhiming. Merger premium, VAM and Impairment of Goodwill [J]. Friends of accounting,2020 (10) :78-84.

3. Liu Aiming, Huang Yuanyuan. An Empirical Study on the Impact of Board Characteristics and Auditor's Reputation on Goodwill Impairment [J]. Chinese Certified Public Accountant, 2019 (05): 33$38+3$.

4. Rao Qian, Hou Xipei. Mergers and Acquisitions and Restructuring Performance Commitments and Listed Companies' Operating Performance-Analysis Based on the Perspective of Performance Commitment Expiration[J]. Business Research, 2017(04): 89-96.

5. Ren Chunyan. Looking at the economic consequences of earnings management from the perspective of corporate investment efficiency -empirical evidence from China's listed companies $[\mathrm{J}]$. Financial and economic research,2012,38 (02) :61-70.

6. Tian Guoshuang, $\mathrm{Gu}$ Manjia. Research on the Impact of Performance compensation Commitment on goodwill impairment [J]. Friends of Accounting,2020(13):58-63.

7. Wang Fusheng, Ji Shanshan, Cheng Fu. Research on the impact of earnings management on the future business performance of listed companies -- based on the comparative perspective of accrual earnings management and real earnings management [J]. Nankai management review,2014,17 (02) :95-106.

8. Xie Haidong, Tan Qiying. Performance commitment, earnings management and corporate performance of A-share backdoor listed companies[J]. Henan Social Sciences, 2018, 26 (09): 34-39. 